P-ISSN : 2655-9811, E-ISSN: 2656-1964

J. Feasible., Vol. 3, No.1, Februari $2021(42-54)$

0 2019 Pusat InkubasiBisnis dan Kew irausahaan

Universitas Pamulang (PINBIK UNPAM)
JURNAL ILMIAH

FEASIBLE

BISNIS, KEWIRAUSAHAAN \& KOPERASI

\title{
Pengembangan Wirausaha Makanan Tradisional Berbahan Baku Ubi Jalar Sebagai Dampak Dari Peningkatan Permintaan Dunia Wisata di Desa Bandorasa Kab. Kuningan
}

\author{
Raden Roro Vemmi Kesuma Dewi ${ }^{1 *}$, Endang Sondari ${ }^{2}$, Denok Sunarsi3 \\ ${ }^{1}$ STAI Al Aqidah Al Hasyimiyyah Jakarta; vemmi_kesumadewi@alaqidah.ac.id* \\ 2Universitas Indraprasta PGRI; endang_sondari@yahoo.com \\ 3Fakultas Ekonomi Universitas Pamulang; denoksunarsi@unpam.ac.id
}

\begin{abstract}
Abstrak
Sektor pariwisata berkembang pesat di Kuningan. Merujuk pada kebijaksanaan otonomi daerah, setiap daerah dapat mengembangkan potensi yang ada, termasuk sektor pariwisata. Sehubungan dengan bidang kewirausahaan, menurut data Badan Pusat Statistik (BPS) tahun 2016, rasio wirausaha di Indonesia sebesar 3,10 persen dari jumlah penduduk sebanyak 225 juta orang. Rasio wirausaha Indonesia mengalami kenaikan yang sebelumnya hanya 1,67\%, kini menjadi 3,1\%. berdasarkan data BPS 2016 dengan jumlah penduduk 252 juta, jumlah wirausaha non pertanian yang menetap mencapai 7,8 juta orang atau 3,1\%. Dengan demikian, tingkat kewirausahaan Indonesia telah melampaui $2 \%$ dari populasi penduduk sebagai syarat minimal suatu masyarakat akan sejahtera. Perkembangan sektor pariwisata memberikan kesempatan untuk membangun bidang kewirausahaan, khususnya di bidang kuliner. Bidang kuliner ini dapat mendukung kegiatan pariwisata dengan memperkenalkan makanan tradisional yang merefleksikan karakter budaya dan warisan lokal dari setiap daerah. Kajian ini menggunakan metode kualitatif dengan mencoba untuk memetakan lima kekuatan yang menentukan intensitas kompetitif dalam industri (5 kekuatan Porter), yaitu: (1) produk pengganti, (2) pesaing yang kompetitif, (3) pendatang baru, (4) penawaran supplier, dan (5) penawaran pembeli. Hasil pemetaan ini dapat dijadikan strategi pengembangan bisnis seni kuliner tradisional dengan metode analisis SWOT. Tulisan ini merekomendasikan sebuah strategi untuk mengembangkan bisnis seni kuliner tradisional melalui kegiatan pariwisata. Selanjutnya diharapkan melalui pengembangan sektor pariwisata dapat memberikan dampak positif untuk perkembangan kewirausahaan di Kuningan. Hasil yang ditemukan adalah ada peningkatan pendapatan masyarakat dalam berwirausaha dengan menggunakan metode baru ini dibandingkan metode konvensional.
\end{abstract}

Kata kunci: Strategi kewirausahaan; Makanan tradisional; Pariwisata

\begin{abstract}
Tourism sectoris rapidly growing in Kuningan. Through regional autonomy policy enables each region to develop the existing potential sectors including tourism sector. In relation to the field of entrepreneurship, according to data from the Central Statistics Agency (BPS) in 2016, the entrepreneurial ratio in Indonesia is 3.10 percent of the population of 225 million people. Indonesia's entrepreneurial ratio experienced an increase of only 1.67\%, now to 3.1\%. Based on
\end{abstract}


BPS 2016 data with a population of 252 million, the number of non-agricultural entrepreneurs who settled reached 7.8 million people or 3.1\%. Thus, the level of Indonesian entrepreneurship has exceeded $2 \%$ of the population as a minimum requirement for a society to prosper. The development of tourism sector provides opportunities for developing of entrepreneurs particularly culinary artisans, in which culinary can support the tourism activities by reviving some traditional food which reflects the local culture and wisdom and has the unique character of a region. By using qualitative methods, this study tries to map the fife force that determine the competitive intensity in industry (Porter's five force) i.e (1) substitute products, (2) competitive rivalry, (3) new entrants, (4) bargaining power of suppliers and (5) bargaining power of buyers. Afterwards, the result of the mapping shall be composed as a business development strategy of traditional culinary artisans with SWOT analysis method. This paper recommends a strategy to develop the business of traditional culinary artisans through tourism activities. It is therefore expected that the development of the tourism sector can provide positive impact to the development of entrepreneurship in Kuningan.

Key words: Strategy; Entrepreneurship; Traditional culinary; Tourism.

$\left.{ }^{*}\right)$ Korespondensi penulis

\section{PENDAHULUAN}

Wilayah Kabupaten Kuningan tidak saja dikenal dengan keindahan alamnya sebagai objek wisata. Sektor ekonomi pun memiliki potensi yang dapat dikembangkan menjadi unggulan daerah. Tanahnya sangat cocok untuk menanam ubi jalar sehingga sebagian besar petani di daerah tersebut banyak yang bercocok tanam ubi jalar. Ubi ini banyak terdapat di Bandorasa Kecamatan Cilimus.

Pariwisata dan makanan merupakan duet ideal, manakala ekses dari kegiatan pariwisata selalu membutuhkan makanan, sesuai dengan fitrah manusia atau wisatawan yang selalu tak bisa berhenti berkonsumsi. Wisata kuliner menempatkan makanan sekaligus sebagai subjek dan media, sebagai destinasi dan alat bagi pengembangan pariwisata (Virna, 2007). Seiring dengan perubahan global, paradigma pariwisata Indonesia sudah memperlihatkan perubahan yang signifikan. Pada masa lalu spektrum pembangunan pariwisata lebih diorientasikan hanya pada beberapa kawasan penting saja, sementara dilihat dari kecendrungan perubahan pasar global yang lebih mengutamakan sumber daya lokal sebagai destinasi pariwisata (Kardigantara dan Goeltom, 2007). Sehubungan dengan trend wisata tersebut pengembangan wisata kuliner berbasis makan tradisional berbahan baku ubi jalar (boled) dapat dikembangkan sebagai salah satu produk wisata, dimana makanan dengan perspektif kelokalan dapat meningkatkan perekonomian masyarakat lokal, bukan hanya bagi para petani sebagai penyedia bahan baku makanan, tapi juga meningkatkan pendapatan para wirausahawan makanan cemilan berbahan baku ubi.

Wirausaha dalam bahasa sansekerta terdiri dari kata wira dan usaha, wira artinya manusia unggul, teladan, berbudi luhur, berjiwa besar, berani, pahlawan/pendekar kemajuan, dan memiliki keagungan watak sedangkan usaha adalah melakukan kegiatan usaha. Wirausaha memiliki berbagai karakter positif yang tidak dimilki oleh para pengusaha biasa. Mereka adalah orangorang yang kreatif dan inovatif dalam mengembangkan peluang-peluang usaha menjadi kesempatan usaha yang menguntungkan dirinya dan masyarakat konsumennya. Mereka bukan sekedar orang yang memiliki keterampilan berbisnis, namun juga memiliki kepemimpinan pribadi yang tinggi, baik tercermin dari daya juang 
yang tinggi, kesabaran dalam menghadapi berbagai tantangan, dan toleransi terhadap ketidak menentuan.

Entrepreneur diambil dari bahasa Perancis yang berarti 'between taker' atau 'go between' yang berarti 'wiraswasta'. Sedangkan di Indonesia istilah "wiraswasta" pertama kali dipopulerkan oleh Dr. Soeparman Soemahamidjaja pada awal tahun 1980. Kemudian pada zaman orde baru penggunaan istilah kewiraswastaan diganti dengan istilah wirausaha (kewirausahaan). Penggunaan istilah entrepreneur dalam pembahasan ini adalah istilah yang sudah global/mendunia. Azwar Idris dalam Bukori Alma (2010)

Makanan adalah hal yang penting dari kehidupan, makanan merupakan industri terbesar, ekspor terbesar dan sebagian merupakan sebuah kesenangan dan makanan berarti sebuah kreativitas dan keragamanan (Belasco, 2006). Dalam konteks pariwisata kuliner dapat memberikan nilai tersendiri bagi pariwisata. Mengkonsumsi produk makanan merupakan representasi dari salah satu kegiatan yang menyenangkan dan dipertimbangkan dalam mengunjungi sebuah negara (Frochot, 2003). Bahkan dalam penelitiannya Saleh (2012) menyebutkan bahwa kenyataannya wisatawan akan menjadikan pengurangan budged untuk aktivitas sebagai alternatif terakhir bahkan penelitian satu pertiga budget wisatawan digunakan untuk mengkonsumsi produk kuliner. Dengan demikian tampak bahwa sektor kuliner adalah sebuah peluang yang cukup baik bagi sektor pariwisata secara global, dimana pengembangan wisata kuliner akan dapat meningkatkan minat pengunjung dan meningkatkan pendapatan dari sektor pariwisata, sehingga membangun sebuah produk kuliner merupakan bagian yang penting dalam membangun pariwisata secara keseluruhan.
Pernyataan tersebut semakin mengerucutkan arah pembangunan produk kuliner, bahwa ternyata permintaan wisatawan cukup besar terhadap produk kuliner tradisional yang mencerminkan keunikan, kelangkaan dan identitas dari sebuah negara atau daerah yang tidak dapat ditemui dinegara atau daerah lain. Pengembangan produk dapat didefinisikan sebagai pemeriksaan produk dan jasa dalam rangka untuk mengidentifikasi peluang perbaikan, kepuasan pelanggan dan keuntungan (Waller, 1996).

Pola seseorang memilih dan mengkonsumsi makanan akan sangat dipengaruhi oleh lingkungan sekitar, baik lingkungan yang berupa makanan lain disekitar makanan tersebut, lingkungan fisik dimana makanan tersebut berada, lingkungan sosial, lingkungan ekonomi dan budaya. (Frewer dan Trijp, 2007).

Dalam pengembangan kuliner termasuk dalam klasifikasi jasa yang disertai dengan produk. Dittmer dan Keefe (2009) menyatakan bahwa dalam industri makanan beverage terdapat produk dan jasa yang kemudian menciptakan sebuah nilai bagi konsumen. Waller (1996) menyatakan bahwa tujuan utama dari pengembangan produ/jasa adalah agar memungkinkan identifikasi pengaruh produk, layanan dan produk yang disertai layanan terhadap keberhasilan operasional, oleh sebab itu dalam pengembangan sebuah wisata kuliner terdapat dua dimensi yang harus di perhatikan yaitu membangun kuliner sebagai sebuah layanan, sehingga pengembangan sebuah wisata kuliner tidak hanya di artikan sebagai pengembangan makanan produk yang mendukung kegiatan pariwisata, tetapi membangun sebuah wisata kuliner juga termasuk membangun sebuah layanan. Dan dalam membangun layanan dalam kuliner akan membutuhkan 
kerjasama dan partisipasi dari setiap stakeholder internal dalam sebuah wilayah.

Pariwisata merupakan kegiatan kemanusiaan yang berhubungan dengan antar orang baik dari negara yang sama ataupun antar negara atau hanya dari daerah geografis yang terbatas. Didalamnya termasuk tinggal untuk sementara waktu daerah lain atau negara lain atau benua lain untuk memenuhi berbagai kebutuhan kecuali kegiatan untuk memperoleh penghasilan, meskipun pada perkembangannya batasan memperoleh penghasilan menjadi kabur (Wahab, 2002).

Sejalan dengan pendapat diatas, menurut Warpani (2007), wisata adalah perjalanan yang dilakukan oleh seseorang atau sekelompok orang mengunjungi tempat tertentu secara sukarela dan bersifat sementara dengan tujuan berlibur atau tujuan lain yang bukan untuk mencari nafkah.

Ada kesamaan dari definisi yang diberikan oleh beberapa ahli, yaitu bahwa pariwisata menyangkut perpindahan tempat secara sementara, dalam rangka mencari sebuah kesenangan dan bukan mencari nafkah.

\section{Permintaan Wisata}

Burkart dan Madlik dalam Vanhome (2005) menyatakan bahwa determinasi dari permintaan wisata adalah beberapa faktor yang ada dalam masyarakat yang dapat menggerakan dan menentukan limit volume permintaan dari sebuah populasi untuk berlibur dan melakukan perjalanan.

Menurut Wahab (1987) permintaan erat kaitannya dengan harga-harga pasar merupakan faktor yang paling menentukan, namun pariwisata hubungan fungsional yang terjadi pada permintaan tidaklah sesederhana itu. Banyak faktor yang turut mempengaruhi pelanggan (wisatawan) untuk melakukan perjalanan ke suatu daerah tujuan wisata tertentu atau menunda. Faktor-faktor itu tampak begitu rumit.

Meddleton dalam Vanhone (2005) menyimpulkan bahwa hal-hal yang mempengaruhi permintaan wisata adalah, faktor ekonomi, perbandingan harga, faktor demografi, faktor geografik, sosio-culture yang berkaitan dengan sikap penerimaan terhadap orang asing, mobilitas, regulasi pemerintaan, media komunikasi dan informasi serta teknologi komunikasi.

Basis utama permintaan wisata adalah ketersediaan waktu dan uang (Kelly dan Dunn pada Damanik dan Weber, 2006). Sedangkan menurut Wahab (1989) membagi permintaan pariwisata menjadi dua yaitu permintaan potensial dan permintaan nyata. Permintaan potensial adalah sejumlah orang yang memenuhi anasir-anasir pokok suatu perjalanan dan arena itu mereka ada di keadaan siap untuk berpergian, sedangkan permintaan aktual adalah orang orang yang secara nyata berpergian kesuatu daerah tujuan wisata. Perbedaan jumlah permintaan potensian dan aktual merupakan kancah usaha bagi orang orang pemasaran.

Dengan demikian maka pengembangan pariwisata diharapkan menjadi orang yang semula hanya berkeinginan untuk berwisata menjadi secara nyata melakukan perjalan wisata juga diharapkan untuk kembali mengadakan perjalanan.

\section{Penawaran Wisata}

Penawaran wisata merupan hal hal yang dapat diberikan atau ditawarkan kepada wisatawan. Elemen penawaran wisata biasa disebut dengan triple A yaitu atraksi, aksesabilitas dan amenitas (Damani dan Webber, 2006) Atraksi merupakan objek wisata yang memberikan kenikmatan kepada wisatawan.

Aksesabilitas mencakup seluruh infrastruktur transportasi yang mendukung 
kegiatan perpindahan dan aktivitas wisatawan.

Amenitas merupakan layanan ataupun infrastruktur tambahan yang secara tidak langsung dapat mendukung kegiatan wisata tapi merupakan bagian dari kebutuhan pariwisata. Kualitas produk wisata mencakup empat hal yaitu keunikan, originalitas, outentisitas dan diversifikasi produk.

Jenis-jenis wisata menurut Nyoman $\mathrm{S}$ Pendit dalam Suprapto (2005) membagi kegiatan wisata berdasarkan jenis jenisnya.

1. Wisata alam yang terdiri dari :

a. Wisata Pantai (Marine tourism), merupakan kegiatan wisata yang ditunjang oleh sarana dan prasarana untuk berenang, memancing, menyelam, dan berolahraga air lainnya, termasuk sarana sarana dan prasarana akomodasi, makanan dan minuman.

b. Wisata Etnik (Etnik tourism), merupakan perjalanan untuk mengamati perwujudan kebudayaan dan gaya hidup masyarakat yang menarik.

c. Wisata Cagar Alam (Ecotourism), merupakan wisata yang banyak dikaitkan dengan kegemaran akan keindahan alam, kesegaran hawa udara dipegunungan, keajaiban hidup binatang (margasatwa) yang langka, serta tumbuh tumbuhan yang jarang terdapat ditempat tempat lain.

d. Wisata Buru, merupakan wisata yang dilakukan di negeri-negeri yang memang memiliki daerah atau hutan tempat berburu yang dibenarkan oleh pemerintah dan digalakan oleh berbagai agen atau biro perjalanan.

e. Wisata Argo, merupakan jenis wisata yang mengorganisasikan perjalanan ke proyek proyek pertanian, perkebunan, dan ladang pembibitan dimana wisata rombongan dapat mengadakan kunjungan dan peninjauan untuk tujuan studi maupun menikmati segarnya tanaman disekitarnya.

2. Wisata Sosial-Budaya, yang terdiri :

a. Peninggalan sejarah kepurbakalaan dan monument, wisata ini termasuk golongan budaya, monument nasional, gedung bersejarah, kota, desa, bangunan bangunan keagamaan, serta tempat tempat bersejarah lainnya seperti tempat bekas pertempuran (battle fields) yang merupakan daya tatik wisata utama dibanyak negara.

b. Museum dan fasilitas budaya lainnya, merupakan wisata yang berhubungan dengan aspek alam dan kebudayaan disuatu kawasan atau daerah tertentu. Museum dapat dikembangkan berdasarkan pada temanya, antara lain museum arkeologi, sejarah, etnologi, sejarah alam, seni dan kerajinan, ilmu pengetahuan dan teknologi, industri, ataupun dengan tema khusus lainnya.

\section{Tantangan Dalam Pengembangan Makanan Tradisional}

Usaha mengembangkan ekowisata kuliner bukan suatu hal yang mudah. Tantangannya adalah bagaimana dapat mengkoordinasikan semua stakeholder internal masing-masing agar dapat memaksimalkan peranan dan fungsinya. Stakeholder internal yang berperan dalam pengembangan sektor pariwisata adalah pemerintah. Baik pemerintah daerah maupun pemerintah pusat, investor dan pengusaha wisata, karyawan sektor pariwisata dan masyarakat. Purnamasari (2008) yang menyebabkan turnover usaha wisata cukup tinggi, disain produk yang kurang menarik, ketersediaan bahan dasar, ukuran yang kurang representative serta 
penggunaan teknologi yang masih minim. Dan secara lebih spesifik Colen dan Avieli (2004) menyatakan bahwa standar higienis, pertimbangan kesehatan, gap dalam komunikasi dan kurangnya pengetahuan wisatawan terhadap kuliner lokal merupakan tantangan dalam pengembangan wisata kuliner.

Sedangkan secara lebih komprehensip, Parma (2012) dalam penelitian tentang formulasi strategi pengembangan makanan lokal sebagai produk wisata kuliner di kabupaten kuningan mengadopsi model manajemen restoran oleh Hsu dan Powers dengan membagi variable menjadi dua sudut pandang. Pertama adalah dari sisi penawaran, bahwa aspek yang perlu diperhatikan dalam mengembangkan produk kuliner adalah menu, strategi produksi, pelayanan (service), harga (pricing) dan dekorasi atau suasana lingkungan (décor/ambience/environment). Sedangkan dari sisi permintaan terdapat beberapa hal yang menjadi aspek pertimbangan atau pun penilaian wisatawan yang akan mengkonsumsi masakan lokal, yaitu harga, cita-rasa, aroma, merek, kemasan, kualitas, porsi, lokasi dan fasilitas.

\section{METODE}

Penelitian ini penggunaan pendekatan kualitatif, hasil penelitian merupakan deskripsi interpretasi yang mana peneliti berusaha menjelaskan dan mendiskripsikan setiap obyek yang ditelitinya bersifat tentative dalam konteks waktu dan situasi tertentu. Kebenaran hasil penelitian lebih banyak didukung melalui kepercayaan berdasarkan konfirmasi dengan pihak-pihak yang diteliti.

Penelitian ini lebih menekankan pada proses dan melihat hubungan antar variabel bersifat interaktif yaitu saling mempengaruhi sehingga tidak diketahui mana variabel independen dan mana dependen, Penelitian ini lebih menekankan pada keluasan informasi dan populasi, selanjutnya peneliti membuat generalisasi (kesimpulan sampel diberlakukan pada populasi dimana sampel diambil). Desainnya bersifat umum, untuk menemukan teori, menggambarkan realitas yang kompleks, dan untuk memperoleh pemahaman makna dengan menggunakan teknik pengumpulan data observasi, interview, dan dokumentasi dan peneliti sebagai instrument. Pengumpulan data terjadi interaksi antara peneliti data dengan sumber data. Tehnik yang digunakan dalam penelitian adalah sebagai berikut:

a) Teknik wawancara adalah usaha mengumpulkan informasi dengan mengajukan sejumlah pertanyaan secara lisan untuk-dijawab secara lisan pula dengan ciri utama berupa kontak langsung dengan tatap muka (face to face relationship) antara si pencari informasi (interviewer atau information hunter) dengan sumber informasi (interviewee).

b) Observasi adalah metode pengumpulan data yang digunakan untuk menghimpun data penelitian melalui pengamatan dan pengindraan.

c) Teknik dokumentasi merupakan teknik pengumpulan data dengan sumber bukan manusia, non human resources, diantaranya dokumen berupa gambar atau foto dilapangan.

\section{HASIL dan PEMBAHASAN}

\section{Objek Wisata di Kabupaten Kuningan}

Banyak objek wisata yang bisa dijumpai di Kuningan berupa wisata alam, wisata ziarah, wisata budaya, dan lainnya. Berikut daftar tempat wisata di daerah Kuningan Jawa Barat:

\section{Wisata Alam}

\section{a. Taman Wisata Alam Linggarjati}

Taman Wisata Alam Linggarjati terletak Objek wisata ini selain 
memiliki panorama indah udara sejuk \& segar, terdapat bangunan bersejarah gedung perjanjian antara pemerintah Indonesia dengan pemerintah Belanda.

b. Waduk Darma

Waduk penampungan air untuk pengairan dan perikanan juga merupakan salah satu objek wisata yang ada di daerah Kuningan. Area waduk tersebut bisa untuk sarana olahraga dan rekreasi dan juga tersedia fasilitas kolam renang anak, perahu motor, areal camping, dan lainnya.

\section{c. Talaga Remis}

Talaga Remis merupakan perpaduan antara pesona alam pegunungan dengan danau yang memiliki air yang sejuk dan jernih

\section{Air Terjun Sidomba}

Objek Wisata Air Terjun Sidomba terletak di Desa Peusing Kecamatan Jalaksana Kabupaten Kuningan. Diantara objek wisata tersebut terdapat juga beberapa fasilitas yaitu saung, restaurant, arena bermain anak, dan tempat untuk berkemah.

\section{d. Pemandian Air Panas Sangkan-} hurip

Objek wisata Sangkanhurip terletak di Kecamatan Cilimus Kabupaten Kuningan yang mana memiliki air panas yang kaya akan sulfur yang berasal dari gunung Ciremai.

\section{Wisata Ziarah}

\section{a. Balong Keramat Darmaloka}

Balong Keramat Darmaloka merupakan danau bekas peninggalan pada jaman dahulu dimana para Walisanga berada di tempat tersebut dalam rangka penyebaran agama Islam yang mana terdiri dari beberapa bagian diantaranya Bale Kambang, Sumber Air Cibinuang,
Balong Bangsal, Balong Ageung, dan Balong Beunteur.

b. Gua Maria

Gua Maria merupakan tempat ziarah para umat Katolik yang memiliki sejarah panjang di antara gua Maria yang juga berada di negara lain.

c. Cibulan

Objek wisata tersebut selain kolam pemandian juga terdapat tujuh sumber mata air yang dikeramatkan yang dinamakan Tujuh Sumur.

\section{Wisata Budaya}

a. Museum Linggarjati

Gedung ini merupakan gedung bersejarah yang mana dulunya pernah digunakan untuk tempat dilaksanakannya Perjanjian Linggarjati pada tahun 1946 silam antara Indonesia dan Belanda.

\section{b. Taman Purbakala Cipari}

Taman Purbakala Cipari merupakan tempat wisata pendidikan yang juga terdapat museum di lokasinya. Menurut sejarah, situs Cipari ditemukan pada tahun 1972 yang memiliki ciri dari kebudayaan masa prasejarah.

\section{Ubi Jalar (Boled)}

Dalam ubi jalar terdapat serat alami yang membantu dalam menyehatkan pencernaan. Adapun macam macam makanan hasil olahan berbahan baku ubi jalar sbb: ubi goreng tepung, es krim, keripik, donat, kue, brownis ubi, mie, selai/saus, bubur, salad, lontong ubi, getuk ubi, dan lain lain. Bisnis olahan makanan berbahan dasar ubi jalar punya peluang pasar yang cukup menggembirakan. PT.Galih Estetika Indonesia, perusahaan pengolahan ubi jalar yang berlokasi di Desa Bandorasa mampu mengekspor 60 ton berbagai jenis produk makanan dengan bahan dasar ubi jalar ke Korea dan Jepang. Produk makanan 
tersebut, di antaraya dalam bentuk pasta ubi jalar, daigaku, slice, solid, dice cut, powder, taiko, chip dan pigmen ubi jalar.

Permintaan berbagai jenis oleh-oleh Kabupaten Kuningan semakin meningkat, seiring dengan gencarnya promosi pemerintah terkait usaha pariwisata. Perkembangan usaha pariwisata Kabupaten Kuningan dapat menciptakan dunia usaha baru untuk perkembangan pembangunan ekonomi masyarakat setempat. Penjual makanan khas Kuningan di Jalan Cilimus, menerangkan setelah ramai pariwisata Kuningan pedagang makanan khas kini bermunculan. Sehingga semakin marak pula penjual oleh-oleh khas daerah setempat, berdampak pada daya beli masyarakat semakin membaik.

Sehubungan dengan trend wisata tersebut pengembangan wisata kuliner berbasis makan tradisional berbahan baku ubi jalar (boled) dapat dikembangkan sebagai salah satu produk wisata, dimana makanan dengan perspektif kelokalan dapat meningkatkan perekonomian masyarakat lokal, bukan hanya bagi para petani sebagai penyedia bahan baku makanan, tapi juga meningkatkan pendapatan para wirausahawan makanan cemilan berbahan baku ubi. internet sudah menjadi bagian dari keseharian masyarakat masa kini. Promosi melalui jaringan tersebut akan bisa lebih cepat mendapatkan respon dari khalayaknya. Dengan tampilan yang aplikatif dan interaktif, media internet sebagai strategi pemasaran modern atau baru akan lebih menarik minat masyarakat untuk menelusuri promosi yang ditampilkan.

\section{Pembahasan}

Pariwisata dan makanan merupakan duet ideal, manakala ekses dari kegiatan pariwisata selalu membutuhkan makanan, sesuai dengan fitrah manusia atau wisatawan yang selalu tak bisa berhenti berkonsumsi.
Wisata kuliner menempatkan makanan sekaligus sebagai subjek dan media, sebagai destinasi dan alat bagi pengembangan pariwisata (Virna, 2007).

Tabel 1. Data Hasil Tani

\begin{tabular}{|lll|}
\hline Sep-Feb (hujan) & 111 & ton \\
\hline Mart-Agt (panas) & 125 & ton \\
\hline
\end{tabular}

HASIL TANI UBI JALAR PERTAHUN

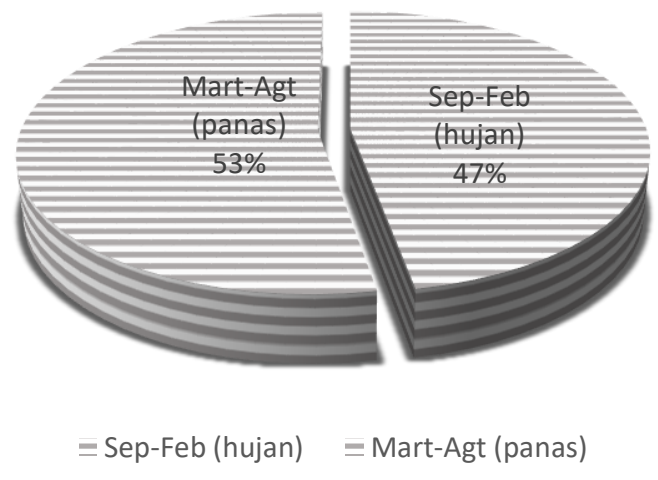

Grafik 1. Hasil Tani Ubi Jalar Pertahun

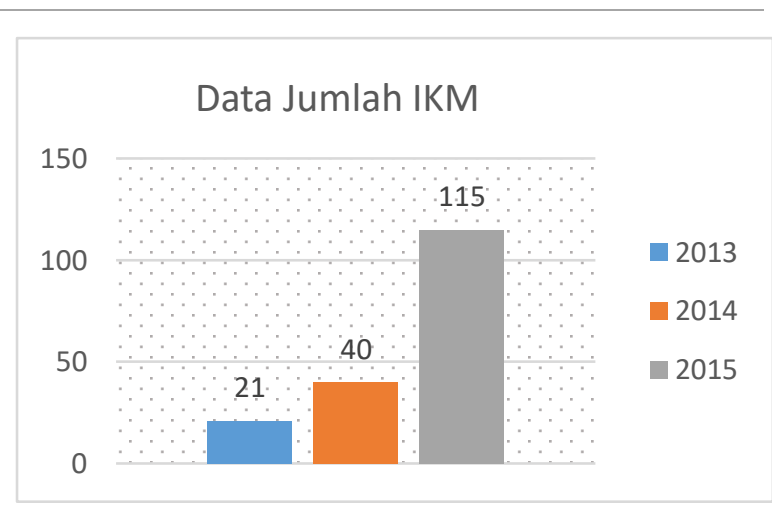

Grafik 2. Data IKM Bandorasa

\section{Permodalan}

Masalah mendasar usaha kecil yang paling menonjol menyangkut menyediakan pembiayaan usaha atau modal usaha. Kebutuhan modal sangat terasa pada saat seseorang ingin memulai usaha baru.

Biasanya bila motivasinya kuat, seseorang akan tetap memulai usaha kecil tetapi dengan modal seadanya. Pada usaha 
yang sudah berjalan, modal tetap menjadi kendala lanjutan untuk berkembang. Masalah yang menghadang usaha kecil menyangkut kemampuan akses pembiayaan, akses pasar dan pemasaran, tata kelola manajemen usaha kecil serta akses informasi. Kesulitan usaha kecil mengakses sumber-sumber modal karena keterbatasan informasi dan kemampuan menembus sumber modal tersebut. Padahal pilihan sumber modal sangat banyak dan beragam.

Lembaga keuangan bank adalah sumber modal terbesar yang dapat dimanfaatkan oleh pelaku usaha kecil. Namun untuk bermitra dengan bank, usaha kecil dituntut menyajikan proposal usaha yang feasible atau layak usaha dan menguntungkan. Disamping itu lembaga keuangan bank mensyaratkan usaha kecil harus bankable alias dapat memenuhi ketentuan bank. Inilah persoalannya. Akibat bank berlaku prudent atau hati-hati, maka makin mempersulit usaha kecil untuk mengakses sumber modal. Usaha kecil di bandorasa yang sulit mengakses bank akan mencari jalan pintas. Kemana lagi kalau bukan kepada para pelempar uang alias rentenir tetapi usaha kecil harus rela dengan biaya yang mencekik. Seolah-olah, usaha kecil tidak mempermasalahkan biaya bunga yang tinggi dari rentenir. Mereka terpaksa memakai uang rentenir karena terpaksa akibat sulit mengakses modal dari bank.

\section{Kemasan}

Kemasan makanan tradisional: Kemasan makanan tradisional berupa seperti daun pisang, rumput, kulit hewan, kerang, dan sebagainya. Kemasan ini digunakan oleh orang terdahulu hanya untuk mewadahi suatu makanan dan sebagai perlindungan dari kemasan makanan tersebut dari buruknya cuaca maupun dari debu, bakteri, dan sejenisnya. Selain itu kemasan tradisional ini di awal berfungsi untuk membawa makanan yang tidak habis dimakan.

Kemasan makanan modern: Kemasan ini adalah kemasan yang ada di zaman kita sekarang ini. Di tahun 2015, Kemasan makanan yang telah beredar dipasaran mulai bertambah banyak, beraneka ragam baik desain dan bentuk. Salah satu perusahaan packaging makanan dari kertas adalah greenpack. Kemasan modern, juga telah mengganti nilai fungsional dari kemasan tradisional. Kemasan modern ini juga banyak digunakan oleh pengusaha sekarang untuk kepentingan promosi maupun strategi untuk menarik perhatian pelanggan. Jadi jelas sudah harus menggunakan kemasan makanan modern apabila ingin meningkatkan omzet perusahaan. Di Bandorasa para pelaku industri kecil dominan masih menggunakan peralatan dan kemasan tradisional seperti menggunakan perekat dengan cara membakar katong plastik dengan lilin.

\section{Saluran distribusi/Pemasaran}

Pemasaran ialah kegiatan yang bertujuan untuk menciptakan pasar akan suatu produk. Menjual produk barang maupun jasa intinya ada pada pemasaran, karena pada bagian ini yang sangat menentukan grafik penjualan sehingga mendapatkan keuntungan yang besar. Marketing konvensional hingga saat ini masih dilakukan, dengan konsekuensi biaya operasional yang tinggi seiring meluasnya wilayah pemasaran. Pemasaran berbasis jaringan internetpun gencar dilakukan. Karena e-marketing sangat mengutamakan kepuasan pelanggan dan selalu berusaha dekat dan mengerti konsumen, maka taktik dan strateginya adalah usaha-usaha untuk mencapai sasaran-sasaran yang salah satunya customer service, misalnya meningkatkan interaksi dengan konten yang berbeda di site dan meningkatkan jumlah 
customers yang aktif menggunakan online service. Salah satu contoh dari taktiknya yaitu mengembangkan strategi yang melihat pada tipe-tipe pesan yang dikirimkan lewat e-mail kepada customers. Taktik dalam pemasaran berbasis internet berhubungan erat dengan e-tools yang mencakup email opt-in, web site, dan digital media channels seperti pameran virtual, iklan display, sponsorship, dan paid search. Dalam membuat taktik, diperlukan pengertian mengenai hal-hal apa saja yang dapat dilakukan dan tidak dapat dilakukan oleh masing-masing peralatan tersebut. Actions berarti rencana-rencana tindakan yang akan dilakukan. Seiring perkembangan teknologi dan informasi juga, mobile marketing yang awalnya merupakan kegiatan pemasaran melalui multimedia billboard dan berbagai banner, sekarang bergerak menjadi lewat telepon seluler dan smartphone yang dapat diakses dimanapun dan kapanpun. Biasanya mobile marketing ini mengirimkan pesanpesan untuk memasarkan produk atau mengundang customers untuk mengunjungi web sitenya. Mobile marketing pada saat ini banyak digunakan oleh perusahaanperusahaan. Hal ini dikarenakan, mereka sadar bahwa sekarang orang-orang banyak yang menggunakan ponselnya untuk mengakses internet, dan semakin lama penggunanya semakin bertambah. Kegiatan pemasaran yang dilakukanpun akan lebih banyak menggunakan internet dan mobile daripada media televisi, radio, atau media konvensional lainnya karena perkembangan zaman dan teknologi tersebut. Yang di lakukan sebagian besar industri makanan di bandorasa adalah cara yang masih konvensional, karena belum seluruhnya pelaku industri mengenal teknologi komunikasi modern berupa internet.

Terlebih lagi sekarang pengguna smart phone dan smart phone-smart phone lainnya sangat banyak di Indonesia. Hal ini dapat menjadi peluang untuk memasarkan produk-produk perusahaan kepada konsumen. Dahulu, sebelum teknologi berkembang, kegiatan pemasaran harus dilakukan dengan cara tradisional seperti iklan dan secara personal. Sekarang kegiatan pemasaran dapat dilakukan dengan lebih efektif dan efisien menggunakan internet dan mobile. Ini semua dapat menjadi cara yang ampuh untuk memasarkan produkproduk perusahaan. Tentunya disertai dengan objektif, strategi dan taktik yang tepat.

\section{Praktek Tengkulak}

Sepak terjang para tengkulak inilah yang banyak membawa dampak negatif dibanding dampak positif yang dirasakan oleh para petani, salah satunya yaitu harga beli produksi pertanian yang murah. Bukan tanpa alasan petani lebih memilih menjual produksi pertanian mereka kepada para tengkulak. Petani lebih memilih menjual produk hasil pertanian kepada tengkulak karena keterbatasan modal untuk melakukan pemasaran produksi pertanian sendiri. Dalam hal ini, tengkulak mau memberikan modal kepada para petani pada masa tanam. Baik modal dalam bentuk uang, maupun dalam penyediaan pupuk bahkan pestisida dalam penunjang produksi. Namun setelah panen, hasil produksi harus dijual kepada tengkulak. Peranan tengkulak lainnya yaitu dalam penguasaan pasar. Pasar-pasar yang ada untuk pemasaran hasil produksi pertanian para petani dikuasai oleh tengkulak, sehingga para petani tidak mampu bersaing dalam hal pemasaran produksi pertanian tersebut. Kalaupun mampu bersaing, biasanya ada persaingan yang tidak sehat terjadi disini yang dilakukan oleh para tengkulak. Persaingan tidak sehat berupa tindakan-tindakan yang tidak normal yang dilakukan tengkulak terhadap petani yaitu beban psikologis. Beban psikologis 
berupa ancaman-ancaman yang bisa mengancam jiwa, baik bagi petani maupun keluarganya. Oleh sebab itu juga, para petani enggan bersaing dalam pemasaran produksi pertaniannya, karena tidak ingin mengambil resiko. Demi kesejahteraan petani, diharapkan adanya perhatian khusus baik dari pemerintah daerah setempat maupun pemerintah pusat dalam menangani hal tersebut. Baik dari segi infrastruktur, pendidikan yang berupa pelatihan, modal, ketersediaan bibit yang berkualitas, pupuk dan pestisida, serta pengawasan dalam pemasaran produksi pertaniannya. Agar kesejahteraan bisa dirasakan oleh para petani. Yang terjadi di Bandorasa tengkulak di Bandorasa merajalela, sulit dikendalikan hal tersebut sudah menjadi momok bagi petani ubi jalar sebagai penghasil utama bahan baku cemilan tradisional khas Kuningan.

\section{Perizinan}

Untuk mendirikan suatu badan usaha tak luput dari pentingnya izin usaha sebagai aspek hukum yang harus dipenuhi. Demi keamanan dan kelancaran proses berjalannya suatu usaha diperlukan beberapa syaratsyarat yang harus dipenuhi. Mengingat negara kita ini adalah negara yang berdiri dengan dasar-dasar hukum yang telah ditetapkan dan terbagi dalam pasal-pasal. Selain faktor kesiapan diawal usaha didirikan dan aliran penghasilan yang diperoleh yang tergantung pada minat konsumen terhadap komoditas atau jasa yang dijual, keberlangsungan suatu usaha dipengaruhi juga oleh keberadaan unsur legalitas dari usaha tersebut. Dalam suatu usaha faktor legalitas ini berwujud pada kepemilikan izin usaha yang dimiliki. Dari beberapa industri makanan yang ada di bandorasa masih belum memiliki izin usaha dan belum paham prosedur pengurusan perizinan usahanya.

\section{SIMPULAN}

Permintaan berbagai jenis oleh-oleh di Kabupaten Kuningan semakin meningkat, seiring dengan gencarnya promosi Pemerintah Kabupaten terkait usaha pariwisata. Perkembangan usaha pariwisata Kabupaten Kuningan dapat menciptakan dunia usaha baru untuk perkembangan pembangunan ekonomi masyarakat setempat

Aspek yang perlu diperhatikan dalam mengembangkan produk kuliner adalah menu, strategi produksi, pelayanan (service), harga (pricing) dan dekorasi atau suasana lingkungan (décor/ambience/environment). Sedangkan dari sisi permintaan terdapat beberapa hal yang menjadi aspek pertimbangan atau pun penilaian wisatawan yang akan mengkonsumsi masakan lokal, yaitu harga, citarasa, aroma, merek, kemasan, kualitas, porsi, lokasi dan fasilitas.

Bandorasa optimis karena memiliki sumber daya alam yang begitu besar dan penuh potensi yang berbeda dengan kebanyakan sumber daya alam lainnya di daerah lain. Ubi jalarlah yang menjadi ikon dan kebanggaan masyarakat bandorasa. Pemasaran konvensional, masih menerapkan penjualan dengan personal selling, mengutus banyak orang sebagai salesmen untuk mendatangi rumah-rumah dan mempromosikan sampai menjual produk yang dibawanya. Secara budget tentu saja kurang efektif. internet sudah menjadi bagian dari keseharian masyarakat masa kini. Promosi melalui jaringan tersebut akan bisa lebih cepat mendapatkan respon dari khalayaknya. Dengan tampilan yang aplikatif dan interaktif, media internet sebagai strategi pemasaran modern atau baru akan lebih menarik minat masyarakat untuk menelusuri promosi yang ditampilkan. Evaluasi kegiatan usaha dengan metode analisis SWOT. 
Analisa SWOT biasanya berupa arahan ataupun rekomendasi untuk mempertahankan kekuatan dan untuk menambah keuntungan dari segi peluang yang ada, sambil mengurangi kekurangan dan juga menghindari ancaman. Jika digunakan dengan benar, analisis ini akan membantu untuk melihat sisi-sisi yang terlupakan atau tidak terlihat selama ini. analisis SWOT merupakan instrumen yang bermanfaat dalam melakukan analisis strategi. Analisis ini berperan sebagai alat untuk meminimalisasi kelemahan yang terdapat dalam suatu perusahaan atau organisasi serta menekan dampak ancaman yang timbul dan harus dihadapi.

Disarankan juga kepada para pelaku IKM, menerapkan bauran pemasan dan lebih fokus memperhatikan aspek SDM, aspek pemasaran, aspek produksi, aspek keuangan, aspek regulasi dalam berwirausaha, serta memanfaatkan teknologi informasi \& komunikasi (internet) dalam memperluas saluran distribusi/promosi.

\section{DAFTAR PUSTAKA}

Aris Suprapto, 2005 Analisis penawaran dan permintaan wisata dalam pengembangan potensi pariwisata, Semarang.

Ariyanto, A., Nuryani, A., \& Sunarsi, D. (2020). Pengaruh Store Atmosphere Dan Promosi Terhadap Keputusan Pembelian Pada Alfamart BSD Tangerang Selatan. Jurnal Ekonomi Efektif, 3(1).

Ballesco Warren, 2006, Meal to come, the regent of the university of calofornia,

Buchari Alma, 2010, Kewirausahaan, Alfabeta, Bandung
Colen Erik dan Avieli, Nir, 2004, food in tourism, attraction and impediment, annals of tourism research.

Effendy, A., \& Sunarsi, D. (2020). Persepsi Mahasiswa Terhadap Kemampuan Dalam Mendirikan UMKM Dan Efektivitas Promosi Melalui Online Di Kota Tangerang Selatan. Jurnal Ilmiah MEA (Manajemen, Ekonomi, \& Akuntansi), 4(3), 702-714. https://doi.org/10.31955/mea.vol4.iss 3.pp702-714

Haque, MG., Munawaroh, Sunarsi, D., (2020). Analysis of SMEs Culinary Marketing Strategy During Covid 19 Pancemic: A Study at "Sate Bebek Cilegon" Resto in Cilegon, Banten. International Journal of Education, Information Technology, and Others. Vol.3. Issue 2

Harnanto Sigit, 1993 Perkembangan dampak ekonomi pariwisata

Irmal, I., Gustiarani, E., \& Sunarsi, D. (2020). Pengaruh E-Marketing dan ECRM terhadap E-Loyalty Pengunjung Situs Website www. Cangkirbogor. com. Jurnal Ekonomi Efektif, 2(2).

Jasmani, J., Sutiman, S., \& Sunarsi, D. (2020). Analysis of the Effect of Prices, Promotions and Products on Purchase Interest Impacts on Consumer Satisfaction of VIVO Brand Mobile Phones in South Tangerang Region. Jurnal Ad'ministrare, 7(1), 73-82.

Kasmad, K., Mustakim, M., \& Sunarsi, D. (2020). Increasing Community School Interest Through Service Quality, Prices and Promotion in Vocational High Schools. Journal of Educational Science and Technology (EST), 6(2). Maddinsyah, A., Hidayat, D., Juhaeri, J., Susanto, D., \& Sunarsi, D. (2020). Desain Formulasi Dan Implementasi Bisnis Strategik Dengan Pendekatan Business Model Canvas (BMC) 
Terintegrasi Kerangka Integrated Performance Management System (IPMS) Pada Koperasi Asperindo. Inovasi, 7(2), 67-76.

Parma, I Putu Gede, 2012, Tesis Formulasi Strategi Pengembangan Masakan Lokal sebagai Produk Wisata Kuliner di kabupaten Buleleng, Universitas Udayana.

Pitama, 2009 Pengantar ilmu pariwisata. Yogyakarta

Saleh, Ismail, 2012, Tesis Sustainable Culinary Tourism in Pucak Bogor, IPB, Bogor.

Sobarna, A., Rizal, R. M., Hambali, S., \& Sunarsi, D. (2020). Influence Make a Match Model toward Communication skills in Physical and Health Pedagogical Concept. Solid State Technology, 63(6), 1355-1363.

Sunarsi, D. (2020). Implikasi Digitalisasi Umkm. Digitalisasi UMKM, 57. books.google.com

Sunarsi, D. (2020). Pengaruh Bauran Pemasaran Dan Kualitas Pelayanan Terhadap Kepuasan Konsumen Pada Giant Dept Store Cabang BSD Tangerang. E-Mabis: Jurnal Ekonomi Manajemen dan Bisnis, 21(1).

Wahab, 2002 Management kepariwisataan Pradnya paramita, Jakarta

Waller, Kaith, 1996, Improving food and Beverage performance, Butterworth Heineman, Jordoan Hill, Oxford.

Warpani Suwardjoko, 2007, Pariwisata dalam tata ruang wilayah, ITB, Bandung
Y Kadarusman, D Sunarsi. (2020). Pengaruh Strategi Penetapan Harga Terhadap Peningkatan Jumlah Siswa Pada SMK PGRI Balaraja. JS (JURNAL SEKOLAH) 4 (3), 213-221

Yusuf, A., \& Sunarsi, D. (2020). The Effect of Promotion and Price on Purchase Decisions. Almana: Jurnal Manajemen dan Bisnis, 4(2), 272-279. 